\title{
Relationship between Hand Eczema Severity and Occupational Stress: A Cross-Sectional Study
}

\author{
Meriam Hafsia ${ }^{1 D},{ }^{1,2}$ Imene Kacem (D), ${ }^{2,3}$ Olfa El Maalel, ${ }^{2,3}$ Maher Maoua, ${ }^{2,3}$ Aicha Brahem, ${ }^{2,3}$ \\ Haifa Aroui, ${ }^{2,4}$ Sana El Guedri, ${ }^{2,3}$ Houda Kalboussi $\oplus^{2,3}$ Souhail Chatti, ${ }^{2,3}$ \\ and Najib Mrizek ${ }^{2,3}$ \\ ${ }^{1}$ Department of Occupational Medicine, Sahloul Teaching Hospital, Sousse, Tunisia \\ ${ }^{2}$ University of Sousse, Faculty of Medicine of Sousse, Sousse, Tunisia \\ ${ }^{3}$ Department of Occupational Medicine, Farhat Hachad Teaching Hospital, Sousse, Tunisia \\ ${ }^{4}$ Department of Occupational Medicine, Ibn Jazzar Teaching Hospital, Kairouan, Tunisia
}

Correspondence should be addressed to Imene Kacem; kacem.imane@live.fr

Received 21 June 2019; Revised 2 August 2019; Accepted 20 August 2019; Published 8 October 2019

Academic Editor: E. Helen Kemp

Copyright ( $) 2019$ Meriam Hafsia et al. This is an open access article distributed under the Creative Commons Attribution License, which permits unrestricted use, distribution, and reproduction in any medium, provided the original work is properly cited.

\begin{abstract}
Background. Stress has been recently implicated as a contributing factor of hand eczema (HE) severity. However, published data are both rare and contradictory justifying the need of further research. The purpose of this study was to evaluate the relation between stress and HE severity. Methods. This is a cross-sectional study enrolling all patients who have been attending the Dermato-allergology unit of Farhat Hached University Hospital of Sousse over a period of one year. The HE severity was assessed by the Osnabrück Hand Eczema Severity Index (OHSI). The stress level was assessed by the Perceived Stress Scale-10 (PSS-10) in its validated Arabic version. Results. During the study period, 109 participants meeting the inclusion criteria were identified. The mean age was $40 \pm 9.9$ years with a sex-ratio of 0.8 . Severe eczema was found in 76 participants (69.7\%). A high level of perceived stress was found in $18.3 \%$ of cases. A statistically significant association was noted between HE severity and the high level of perceived stress $(p=0.039, \mathrm{OR}=4.46,95 \% \mathrm{CI}[0.96-20.59])$ and the number of dependent children $\geq 3(p=0.0039, \mathrm{OR}=1.92$, $95 \%$ CI $[0.51-7.22])$. Leisure activity was found to be a protective factor against HE severity $(p=0.031, \mathrm{OR}=0.27,95 \% \mathrm{CI}$ $[0.09-0.80])$. Conclusion. Although the link between the severity of eczema and atopy, wet work, and contact with irritants and allergens is well known, the relation remains questionable for other factors including stress.
\end{abstract}

\section{Introduction}

Hand eczema (HE) is a specific dermatosis because it touches the hand, main tool of work and communication, resulting in a variously felt discomfort [1].

Chronic and severe forms can have a serious impact on the patient's daily life, as it has individual and socioprofessional consequences [1]. Severe forms occur in 5 to $7 \%$ of cases and are likely to lead to major physical and psychological disabilities [2].

HE is a multifactorial pathology in which development and repetitive occurrence are closely linked to the environment. The clinical expression of the disease depends on living conditions, nature of the exposures, and genetic factors.
Factors involved in the onset of relapses and the transition to chronicity are numerous but not clearly identified. They can be endogenous and exogenous [3].

Many studies insist on the role of different factors exacerbating the HE. While a link between the severity of eczema and atopy, wet work, and contact with irritants and allergens is well known, the relation remains questionable for other factors including the stress, whether it is general or work-related $[4,5]$.

Studies on this subject are rare, and the results are contradictory, thus warranting further research so that firm conclusions can be drawn.

The objective of our study was to look for a possible relation between the severity of $\mathrm{HE}$ and occupational stress. 


\section{Methods}

After obtaining the ethics committee approval and the oral patients consent, this cross-sectional and analytical study was performed in the dermato-allergology unit of Farhat Hached Teaching Hospital over one-year period (from 01/ 05/2017 to $31 / 05 / 2018$ ).

Patients consulting for HE diagnosed by a dermatologist and exercising an occupational activity for at least one year were enrolled in this study.

Exclusion criteria were as follows: age under 18 years or above 65 years, patients with no lesions in the hands, and those with other diagnoses of hand dermatosis.

The diagnosis of ACD was clinically made and confirmed by a relevant patch test.

Data were collected using a medical questionnaire and a dermatological clinical examination. The medical questionnaire explored the sociodemographic characteristics (age, gender, educational level, and marital status), occupational data (sector of activity, occupational seniority, occupation, working in a humid environment, means of protection, nd occupational repercussions), lifestyle data (tobacco and alcohol consumption and extraprofessional activities), and medical information (family history of eczema, personal medical history, personal history of allergy, duration of eczema evolution, number of relapses per year, symptoms, and prescription of treatment).

The Perceived Stress Scale PSS-10 in its Arabic version was used to assess the stress level of our population. This scale is composed of 10 items divided into 2 groups. The first group has 6 negative items measuring "perception of stress," while the second group has 4 positive items measuring "coping" or adaptation to stress. A high level of perceived stress is defined by a score more than $27[6,7]$.

Occupational stress was assessed by Siegrest's "effortreward imbalance" questionnaire in its validated Arabic version [8]. This questionnaire is based on the imbalance between the efforts made and the expected rewards. It is a multidimensional tool composed of three scales: the Efforts Scale (5 items), the Rewards Scale (11 items), and the Overinvestment Scale (6 items). The calculation of the effort/ rewards ratio is obtained by the following formula: ratio $=11 / 6 \times$ extrinsic efforts/rewards. A ratio $>1$ defines employees exposed to an imbalance between efforts and rewards.

The dermatological clinical examination focused on the clinical appearance of hand eczema and the extent of lesions.

The HE severity was assessed by the Osnabrück Hand Eczema Severity Index (OHSI) [9]. This tool considers six morphological signs (erythema, scaling, papules, vesicles, infiltration, and fissures) and estimates their extent in the affected area by a four level scale (0 to 3 ). Severe hand eczema was defined as an OHSI score $>7$ [9].

Data were analyzed using SPSS.20.0. Student's " $t$ " test was used to compare two independent series means. Comparison of frequencies was performed with Pearson's chi-squared test. Analyses of the relation between two quantitative variables (e.g., score and age) was done using Pearson's correlation coefficient.
Multivariate analyzes were performed using the logistic regression method to identify determinants of the severity of eczema; the dependent variable was severity of eczema (a binary variable with OHSI score $>$ or $\leq 7$ ), and the explanatory variables were all variables whose $p$ value was less than or equal to $20 \%$ in univariate analysis. For all statistical tests, the significance level $p$ was set at 0.05 . The association was measured by the odds ratio (OR) that was presented with its 95\% confidence interval.

\section{Results}

During the study period, 109 patients with HE were included. The average age was $40 \pm 9.9$ years. HE was more frequent in women $(53.2 \%)$. The majority of patients were married $(75.2 \%)$, and $56 \%$ had at least two children.

Seventy patients $(15.6 \%)$ were working in the healthcare sector, thirteen in the textile industry $(12 \%)$, and eleven in construction field (10.1\%). Average job seniority was $12.9 \pm 9$ years. Regarding the influence of HE on work, only 8 patients $(7.5 \%)$ were transferred from their workstation. Personal history of atopy, revealed by asthma, allergic rhinitis, or allergic conjunctivitis, was found in 25 patients (23\%) without any atopic eczema condition. Sociodemographic and occupational data are summarized in Table 1. Severe HE was noted in 76 participants (69.7\%) according to OHSI score.

Mean score of PSS-10 was $20.1 \pm 8.4$ ranging between 9 and 37 . The majority of the patients reported a moderate stress level (62.4\%). Comparing the efforts made to the rewards at the professional level, 51 participants $(46.8 \%)$ felt unbalanced.

The results of the evaluation of the different levels of perceived and occupational stress among the participants are summarized in Table 2.

A significant association was observed between the severity of $\mathrm{HE}$ and the number of dependent children. A number of dependent children $\geq 3$ was associated with a significant increase in the risk of HE severity $(p=0.039$, $\mathrm{OR}=1.92,95 \% \mathrm{CI}=[1.10-7.22])$. The practice of a leisure activity was associated with a significant decrease in the risk of severity of $\mathrm{HE}(p=0.031, \mathrm{OR}=0.27,95 \% \mathrm{CI}=[0.09-$ $0.80])$. Neither sector of activity nor workstation was significantly associated with the severity of eczema $(p=0.71$ and $p=0.15$, respectively).

However, a statistically significant association between occupational seniority and the severity of eczema was noted with no increased risk ( $p=0.009, \mathrm{OR}=1 ; 95 \%$ CI $[1-1.04])$.

Associations between the severity of $\mathrm{HE}$ and the sociodemographic data, lifestyle habits, medical data, and occupational data are summarized in Table 3.

Regarding the relationship between the severity of eczema and the different levels of stress, a statistically significant association was found between the severity of eczema and the high level of perceived stress $(p=0.039$, $\mathrm{OR}=4.46 ; 95 \% \mathrm{CI}=$ [1.04 to 20.59$]$ ).

Also, a positive significant correlation was found between the Osnabrück score and the PSS score $(p=0.002$, $r=30 \%)$. 
TABLE 1: Sociodemographic and professional data of the participants.

\begin{tabular}{|c|c|c|}
\hline Variables & Number of participants & Percentage \\
\hline \multicolumn{3}{|l|}{ Gender } \\
\hline Woman & 58 & 53.2 \\
\hline Man & 51 & 46.8 \\
\hline \multicolumn{3}{|l|}{ Civil status } \\
\hline Single & 24 & 22 \\
\hline Married & 82 & 75.2 \\
\hline Divorced & 3 & 2.8 \\
\hline \multicolumn{3}{|l|}{ Level of education } \\
\hline Illiterate & 7 & 6.4 \\
\hline Primary & 34 & 31.2 \\
\hline Secondary & 38 & 34.9 \\
\hline Academic & 30 & 27.5 \\
\hline \multicolumn{3}{|l|}{ Socioeconomic level } \\
\hline Low & 2 & 1.8 \\
\hline Middle & 87 & 79.8 \\
\hline High & 20 & 18.3 \\
\hline \multicolumn{3}{|l|}{ Number of children } \\
\hline 0 & 34 & 15 \\
\hline 1 & 14 & 6 \\
\hline 2 & 28 & 4 \\
\hline 3 and more & 33 & 8 \\
\hline \multicolumn{3}{|l|}{ Personal history of atopy } \\
\hline No atopy & 84 & 77 \\
\hline Asthma & 6 & 5.5 \\
\hline Allergic rhinitis & 15 & 13.8 \\
\hline Allergic conjunctivitis & 4 & 3.7 \\
\hline \multicolumn{3}{|l|}{ Professional activity sector } \\
\hline Health & 17 & 15.6 \\
\hline Administration & 9 & 7.6 \\
\hline Construction and public works & 11 & 10.1 \\
\hline Transport & 9 & 8.5 \\
\hline Hairstyle and aesthetics & 4 & 3.7 \\
\hline Chemical industry & 15 & 13.7 \\
\hline Food industry & 2 & 1.8 \\
\hline Wood, mechanical, and electrical industries & 14 & 12.8 \\
\hline Hotel and catering trades & 12 & 11.2 \\
\hline Textile & 13 & 12.3 \\
\hline Others & 3 & 2.7 \\
\hline \multicolumn{3}{|l|}{ Occupation category } \\
\hline Administrative position & 9 & 8.2 \\
\hline Employee & 5 & 6.2 \\
\hline Labor & 72 & 65 \\
\hline Technician & 13 & 11.4 \\
\hline Doctor and paramedical staff & 10 & 9.2 \\
\hline
\end{tabular}

TABLE 2: Distribution of participants by level of stress.

\begin{tabular}{lcc}
\hline Measuring tool & Number $(n)$ & Percentage \\
\hline Score of PSS & & \\
$<14$ & 21 & 19.3 \\
$14-26$ & 68 & 62.4 \\
$>27$ & 20 & 18.3 \\
\hline Effort/rewards imbalance (Siegrist) & & \\
Yes & 51 & 56.8 \\
No & 58 & 53.2 \\
\hline
\end{tabular}

PSS: Perceived Stress Scale. 
TABLE 3: Association between severity HE and sociodemographic data, lifestyle habits, and medical and occupational data.

\begin{tabular}{|c|c|c|c|c|c|c|}
\hline Variables & $\begin{array}{c}\text { Severe HE } \\
\mathrm{A} \pm \mathrm{SD}\end{array}$ & & $\begin{array}{c}\text { Nonsevere HE } \\
\mathrm{A} \pm \mathrm{SD}\end{array}$ & & $p$ value & OR $(95 \% \mathrm{CI})$ \\
\hline Age (years) & $39.8 \pm 9.5$ & & $40.4 \pm 10.7$ & & $p=0.74$ & $0.99(0.95-1.03)$ \\
\hline Duration of the complaint (years) & $7.03 \pm 6.22$ & & $7 \pm 5.38$ & & 0.22 & $1.01(0.95-1.08)$ \\
\hline Number of relapses & $4.57 \pm 2.27$ & & $3.64 \pm 2.74$ & & 0.06 & $1.19(0.98-1.44)$ \\
\hline Days off & $11.5 \pm 24.6$ & & $12.7 \pm 23$ & & 0.97 & $0.99(0.98-1.01)$ \\
\hline & $N$ & $\%$ & $N$ & $\%$ & & \\
\hline $\begin{array}{l}\text { Gender } \\
\text { Woman } \\
\text { Man } \\
\end{array}$ & $\begin{array}{l}38 \\
38 \\
\end{array}$ & $\begin{array}{l}50 \\
50 \\
\end{array}$ & $\begin{array}{l}20 \\
13 \\
\end{array}$ & $\begin{array}{l}60.6 \\
39.4 \\
\end{array}$ & 0.30 & $1.53(0.67-3.53)$ \\
\hline $\begin{array}{l}\text { Civil status } \\
\text { Single } \\
\text { Married } \\
\text { Divorced }\end{array}$ & $\begin{array}{c}15 \\
60 \\
1\end{array}$ & $\begin{array}{c}19.7 \\
78.9 \\
1.4\end{array}$ & $\begin{array}{c}9 \\
22 \\
2\end{array}$ & $\begin{array}{c}27.3 \\
66.6 \\
6.1 \\
\end{array}$ & 0.25 & $\begin{array}{c}1 \\
3.33(0.26-42.21) \\
5.45(0.47-63.18)\end{array}$ \\
\hline $\begin{array}{l}\text { Children number } \\
0 \\
1 \\
2 \\
3 \text { and more } \\
\end{array}$ & $\begin{array}{c}19 \\
8 \\
24 \\
25\end{array}$ & $\begin{array}{c}25 \\
10.5 \\
31.6 \\
32.9\end{array}$ & $\begin{array}{c}15 \\
6 \\
4 \\
8\end{array}$ & $\begin{array}{l}45.5 \\
18.2 \\
12.1 \\
24.2\end{array}$ & 0.039 & $\begin{array}{c}1 \\
0.40(0.14-1.15) \\
0.42(0.11-1.60) \\
1.92(1.10-7.22)\end{array}$ \\
\hline $\begin{array}{l}\text { Sports activity } \\
\text { No } \\
\text { Yes }\end{array}$ & $\begin{array}{c}70 \\
6 \\
\end{array}$ & $\begin{array}{c}92.1 \\
7.9 \\
\end{array}$ & $\begin{array}{c}28 \\
5 \\
\end{array}$ & $\begin{array}{l}84.8 \\
15.2 \\
\end{array}$ & 0.41 & $0.48(0.13-1.70)$ \\
\hline $\begin{array}{l}\text { Leisure activity } \\
\text { No } \\
\text { Yes }\end{array}$ & $\begin{array}{c}69 \\
7 \\
\end{array}$ & $\begin{array}{c}90.8 \\
9.2 \\
\end{array}$ & $\begin{array}{c}24 \\
9 \\
\end{array}$ & $\begin{array}{l}72.7 \\
27.3 \\
\end{array}$ & 0.031 & $0.27(0.09-0.80)$ \\
\hline $\begin{array}{l}\text { Smoking status } \\
\text { No smoking } \\
\text { Current smoking } \\
\text { Weaned smoking }\end{array}$ & $\begin{array}{c}46 \\
23 \\
7 \\
\end{array}$ & $\begin{array}{c}60.5 \\
30.3 \\
9.2 \\
\end{array}$ & $\begin{array}{c}26 \\
6 \\
1 \\
\end{array}$ & $\begin{array}{c}78.8 \\
18.2 \\
3 \\
\end{array}$ & 0.14 & $\begin{array}{c}1 \\
0.25(0.02-2.16) \\
0.54(0.05-5.35)\end{array}$ \\
\hline $\begin{array}{l}\text { Alcoholism } \\
\text { No } \\
\text { Yes } \\
\end{array}$ & $\begin{array}{l}66 \\
10 \\
\end{array}$ & $\begin{array}{l}86.8 \\
13.2 \\
\end{array}$ & $\begin{array}{c}31 \\
2 \\
\end{array}$ & $\begin{array}{c}93.9 \\
6.1 \\
\end{array}$ & 0.45 & $2.34(0.48-11.36)$ \\
\hline $\begin{array}{l}B M I \\
\text { Normal } \\
\text { Overweight and obesity }\end{array}$ & $\begin{array}{l}33 \\
43 \\
\end{array}$ & $\begin{array}{l}43.4 \\
56.6 \\
\end{array}$ & $\begin{array}{l}15 \\
18 \\
\end{array}$ & $\begin{array}{l}45.5 \\
54.5 \\
\end{array}$ & 0.84 & $1.08(0.47-2.47)$ \\
\hline $\begin{array}{l}\text { Personal history of atopy } \\
\text { Yes } \\
\text { No }\end{array}$ & $\begin{array}{l}15 \\
61 \\
\end{array}$ & $\begin{array}{l}19.7 \\
80.3 \\
\end{array}$ & $\begin{array}{l}10 \\
23\end{array}$ & $\begin{array}{l}30.3 \\
69.7 \\
\end{array}$ & 0.22 & $0.56(0.22-1.43)$ \\
\hline $\begin{array}{l}\text { Clinical signs } \\
\text { Itching } \\
\text { Painful } \\
\text { Burning }\end{array}$ & $\begin{array}{c}67 \\
5 \\
4\end{array}$ & $\begin{array}{c}88.2 \\
6.6 \\
5.3 \\
\end{array}$ & $\begin{array}{c}31 \\
1 \\
1 \\
\end{array}$ & $\begin{array}{c}93.9 \\
3.1 \\
3 \\
\end{array}$ & 0.65 & $\begin{array}{c}1 \\
0.54(0.05-5.03) \\
1.25(0.05-26.86)\end{array}$ \\
\hline $\begin{array}{l}\text { Treatment intake } \\
\text { Absent } \\
\text { Occasional } \\
\text { Daily }\end{array}$ & $\begin{array}{l}14 \\
42 \\
20\end{array}$ & $\begin{array}{l}18.4 \\
55.3 \\
26.3\end{array}$ & $\begin{array}{c}4 \\
18 \\
11\end{array}$ & $\begin{array}{l}12.2 \\
54.5 \\
33.3\end{array}$ & 0.62 & $\begin{array}{c}1 \\
1.92(0.50-7.29) \\
1.28(0.51-3.22)\end{array}$ \\
\hline $\begin{array}{l}\text { Irritating products } \\
\text { Yes } \\
\text { No }\end{array}$ & $\begin{array}{l}44 \\
32 \\
\end{array}$ & $\begin{array}{l}57.9 \\
42.1 \\
\end{array}$ & $\begin{array}{c}15 \\
45.5 \\
\end{array}$ & $\begin{array}{c}18 \\
54.5 \\
\end{array}$ & 0.23 & $1.65(0.27-3.75)$ \\
\hline $\begin{array}{l}\text { Wet work } \\
\text { Yes } \\
\text { No }\end{array}$ & $\begin{array}{l}18 \\
58 \\
\end{array}$ & $\begin{array}{l}23.7 \\
76.3 \\
\end{array}$ & $\begin{array}{c}9 \\
24\end{array}$ & $\begin{array}{l}27.3 \\
72.7 \\
\end{array}$ & 0.69 & $0.82(0.32-2.09)$ \\
\hline $\begin{array}{l}\text { Frequent washing } \\
\text { Yes } \\
\text { No }\end{array}$ & $\begin{array}{l}31 \\
45\end{array}$ & $\begin{array}{l}40.8 \\
59.2\end{array}$ & $\begin{array}{l}17 \\
16\end{array}$ & $\begin{array}{l}51.5 \\
48.5\end{array}$ & 0.30 & $0.64(0.28-1.47)$ \\
\hline $\begin{array}{l}\text { Hand protection } \\
\text { Yes } \\
\text { No }\end{array}$ & $\begin{array}{l}12 \\
64 \\
\end{array}$ & $\begin{array}{l}15.8 \\
84.2\end{array}$ & $\begin{array}{c}6 \\
27 \\
\end{array}$ & $\begin{array}{l}18.2 \\
81.8\end{array}$ & 0.75 & $0.84(0.82-2.48)$ \\
\hline
\end{tabular}


TABle 3: Continued.

\begin{tabular}{lccccc}
\hline Variables & $\begin{array}{c}\text { Severe HE } \\
\mathrm{A} \pm \mathrm{SD}\end{array}$ & $\begin{array}{c}\text { Nonsevere HE } \\
\mathrm{A} \pm \mathrm{SD}\end{array}$ & $p$ value & OR (95\% CI) \\
\hline Occupational repercussions & & & & & \\
Work resumption & 69 & 90.8 & 29 & 97.9 & 0.89 \\
Mutation & 5 & 6.6 & 3 & 3 & $1.19(0,10-13,64)$ \\
Other & 2 & 2.6 & 1 & 3 & $0.83(0.05-13.63)$ \\
\hline
\end{tabular}

$\mathrm{A} \pm \mathrm{SD}$ : average \pm standard deviation.

In addition, a positive significant correlation was found between the Osnabrück score and the ratio of effort/rewards imbalance $(p=0.009 p=0.009, r=24 \%)$ (Figure 1).

Multiple binary logistic regression showed that the severity of HE did not seem to be associated with the studied variables.

\section{Discussion}

This cross-sectional epidemiological study carried out in the dermato-allergology unit of Farhat Hached Teaching Hospital of Sousse aims to assess the impact of occupational stress on HE severity.

The clinical evaluation of HE severity has an important role in daily clinical practice as well as in research. For various dermatological diseases such as atopic dermatitis and acne, many validated tools are available allowing an objective severity evaluation $[10,11]$. However, for HE, there is no standardized scoring system. The clinical approach allows only a static evaluation of eczema severity and does not consider the fluctuations of its clinical presentation. Thus, a variety of grading systems are usually considered such as the Hand Eczema Severity index (HECSI) designed by Held et al. [12,13]. This instrument is based on systematic measures of a combination of disease extent and clinical signs. Another approach was used by Coenraads et al. [14], who developed a simple five-point photographic classification system. In 2006, a third scoring system named "the Osnabrück Hand Eczema Severity Index" (OHSI) was published. Despite many similarities with HECSI, the OHSI seems to be simpler and easier allowing a wide use even by nondermatologists $[9,15]$.

In our study, the HE was evaluated by the OHSI score and was classified as severe in $69.7 \%$ of cases. Various results have been published depending on the evaluation methods used.

In the Hald et al.'s study [5], eczema was rated moderate to very severe in $60.3 \%$ of patients using the photographic and moderate guides using the "HECSI" score.

In a recent Danish study, $23.8 \%$ of respondents rated their current $\mathrm{HE}$ as moderate to very severe using the same photographic guide [16].

In most previous studies on risk factors of $\mathrm{HE}$, the focus has been on atopy, skin irritation, and contact dermatitis. In this study, the relationship between some lifestyle factors and the severity of HE was sought.

The severity of HE was correlated with a high level of perceived stress and a number of dependent children $\geq 3$. Leisure activity had been considered as a protective factor. In

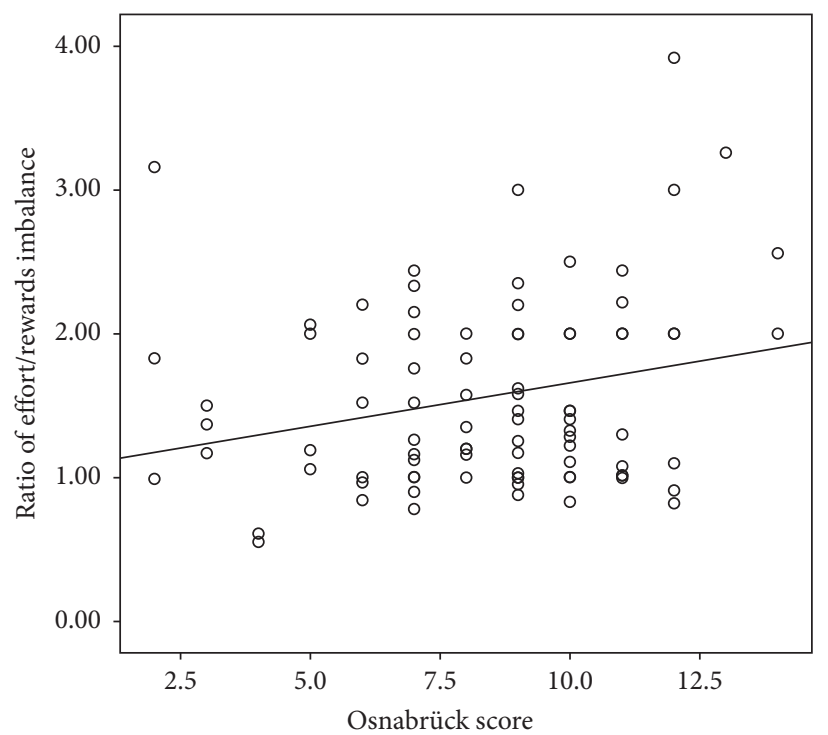

FIGURE 1: Correlation between the severity of HE and work stress.

our study, we found a correlation between the Osnabrück score and effort/reward imbalance suggesting an influence of occupational stress on the severity of eczema. However, no significant association was found after multivariate analysis.

Factors associated with the severity of HE in the literature include advanced age, atopic dermatitis, and frequent flares in the last 12 months and at least 1 positive patch test [5].

Factors associated with a poor prognosis were frequent flares in the last 12 months and unskilled workers. In terms of morphology, fissures and desquamation were also identified as risk factors of poor prognosis [5].

In our study, only the number of dependent children $(\geq 3)$ was associated with eczema severity. This could be explained by family constraints and the high mental and physical burden that could lead to a high level of stress, a delay in physician consultation, and a nonadherence to medication.

According to a German study, $48 \%$ of participants identified stress as a factor influencing their hand dermatosis. Respondents who reported high stress levels felt that their HE was more severe than those who had low levels of stress [17]. The relationship between stress and immune response in $\mathrm{HE}$ is not well studied. Our results suggested that the severity of HE could be influenced by a high level of perceived stress and occupational stress with an imbalance in the efforts provided compared to the rewards at the professional level in $46.8 \%$ of participants. However, the role of stress is difficult to assess 
because patient's ability of adaptation differs from one subject to another even for the same event [18].

Moreover, some published data still debate the above findings. In the study of Böhm et al. [19] involving 122 patients with work-related HE, eczema symptoms were not more severe in patients experiencing more stress and burnout despite their effects on patients ability of adaptation.

In fact, burnout syndrome is linked to chronic exposure to high levels of work stress leading to the exhaustion over time of physical abilities and cognitive and emotional resources that are important to resist negative consequences of stress on health [20].

There are few studies on hand dermatitis, specifically including occupational stress. Most of studies have been focalized in general stress such as family relationships or life events.

In a recent Danish study, enrolling 773 patients with a professional $\mathrm{HE}$, no association was found between the severity of eczema and stress [4].

In. [17], 47.52\% among all patients with hand dermatitis and contact dermatitis, Niemeier et al. reported that stress affects the course of their disease. According to published data, high patient stress response correlates with higher severity scores, more itching, and higher depression scores.

The correlation between stress and the onset and exacerbation of skin disorders that are commonly involved in $\mathrm{HE}$ is not well established $[21,22]$. In fact, people who believe that their skin is sensitive to stress (perceived stress) report more serious symptoms, more severe depression, and more stressful life events [17]. HE has been shown to be more common among those reporting work-related stress [23], but the causal relationship between stress and symptoms has not been established. The psychological influences of stress on the severity and course of this disease have rarely been investigated [19].

As stress has a significant impact on the skin barrier [24], sebaceous secretion [25], cutaneous inflammation [26], and immunity [27], it logically participates in the occurrence of flares of inflammatory dermatoses. This has been demonstrated in psoriasis [28] or atopic dermatitis [29] but not yet in HE.

The psychological stress, frequently present in the professional world, worsens contact dermatitis, as it aggravates a large number of inflammatory diseases [30]. Mechanisms of the effect of stress have been studied in models of allergic contact dermatitis in mice subjected to nonpainful stress.

They showed that stress acts as an adjunct to inflammatory skin responses via norepinephrine released from the skin by the fibers of the sympathetic nervous system. The dendritic cells receiving this danger signal migrate more rapidly and in greater numbers to the ganglia, where they activate a larger number of effector $T$ cells capable of inducing a larger and longer-lasting response [29]. Despite a marked exacerbation of several skin disorders by stress, the effect of stress on human skin has not been well studied [31].

According to a study of changes in the cutaneous barrier induced by stress, the authors concluded that stress could cause a delay in the recovery of cutaneous barrier function [31]. This study suggested that one of the mechanisms contributing to stress-induced exacerbation of certain chronic skin hyperplasias and inflammatory disorders was the stress-induced alteration of homeostasis of skin barrier permeability [31]. Disruption of the cutaneous barrier was associated with an increase in keratinocyte proliferation and in inflammation by cytokine production in the local tissue. Both of these effects could potentially trigger or aggravate inflammatory skin disorders such as eczema and atopic dermatitis and also aggravate contact dermatitis [31]. However, in some experimental studies, exogenous stress has been shown to have potent anti-inflammatory effects through increased endogenous glucocorticoids in mouse models with allergic contact dermatitis [32].

Although our study has the originality of treating the relationship between occupational stress and the severity of $\mathrm{HE}$, an entity that has been rarely described, some limitations must be considered in interpreting the results. It is essentially the limited size of the sample and the relatively short period of the study.

In the same way, our study was interested only in patients who were consultants in the dermatology-allergology unit of Farhat Hached Teaching Hospital of Sousse, thus corresponding to a selected population. This selectivity is a bias towards the extrapolation of results to other populations, but in return, it facilitates the analysis of the data by reducing the heterogeneity of the studied population.

The use of self-questionnaires is a widely used approach in the field of medical research because of its speed and low cost. However, because of its declarative character, results can be influenced by participants' subjectivity. To remedy this deficiency, validated and standardized tools have been used to assess stress.

In our study, the subjective elements of HE were not considered in the assessment of eczema severity. It was performed via the Osnabrück Score which is a simple score that can be used by nondermatologists, particularly in epidemiological studies and in occupational health screening [15].

Finally, given the method used (cross-sectional study), the establishment of causal links between the variables studied could not be done. Furthermore, this study has targeted all the factors that have been incriminated in the literature in the severity of $\mathrm{HE}$.

\section{Conclusion}

According to our study, HE severity seems to be associated with occupational stress. Thus, it is important to consider psychological factors in the follow-up and treatment of the patients. Psychological and educational interventions in addition to dermatological therapy should be an important basis for the management of HE. Similarly, at-risk patients must be identified and have access to training on coping strategies for occupational stress.

\section{Data Availability}

Readers can access the data underlying the findings of our study by contacting the corresponding author through mail. 


\section{Conflicts of Interest}

The authors declare that there are no conflicts of interest regarding the publication of this paper.

\section{References}

[1] C.-J. Le Coza, "Eczéma des mains et maladie professionnelle," Annales de Dermatologie et de Vénéréologie, vol. 137, no. 3, pp. 104-110, 2010.

[2] D. Elston, D. D. F. Ahmed, K. L. Watsky, and K. Schwarzenberger, "Hand dermatitis," Journal of the American Academy of Dermatology, vol. 47, no. 2, pp. 291-299, 2002.

[3] B. Halioua and M.-A. Richard, "Mise au point sur l'eczéma chronique des mains," Annales de Dermatologie et de Vénéréologie, vol. 137, no. 4, pp. 315-327, 2010.

[4] J. A. Sorensen, M. H. Fisker, T. Agner, K. K. Clemmensen, and N. E. Ebbehoj, "Associations between lifestyle factors and hand eczema severity: are tobacco smoking, obesity and stress significantly linked to eczema severity?," Contact Dermatitis, vol. 76, no. 3, pp. 138-145, 2017.

[5] M. Hald, T. Agner, J. Blands et al., "Clinical severity and prognosis of hand eczema," British Journal of Dermatology, vol. 160, no. 6, pp. 1229-1236, 2009.

[6] V. Langevin, M. François, S. Boini, and A. Riou, "Risques psychosociaux :outils d'évaluation « Perceived Stress Scale (PSS): Échelle de stress perçu »" INRS, vol. 143, pp. 101-104, 2015.

[7] T. Almadi, I. Cathers, A. M. Hamdan Mansour, and C. M. Chow, "An Arabic version of the perceived stress scale: translation and validation study," International Journal of Nursing Studies, vol. 49, no. 1, pp. 84-89, 2012.

[8] I. Niedhammer, J. Siegrist, M. F. Landre, M. Goldberg, and A. Leclerc, "Psychometric properties of the French version of the effort-reward imbalance model," Revue d'Epidemiologie et de Santé Publique, vol. 48, no. 5, pp. 419-437, 2000.

[9] M. Dulon, C. Skudlik, M. Nübling, S. M. John, and A. Nienhaus, "Validity and responsiveness of the Osnabrück Hand Eczema Severity Index (OHSI): a methodological study," British Journal of Dermatology, vol. 160, no. 1, pp. 137-142, 2009.

[10] B. M. Burke and W. J. Cunliffe, "The assessment of acne vulgaris-the Leeds technique," British Journal of Dermatology, vol. 111, no. 1, pp. 83-92, 1984.

[11] B. Kunz, A. P. Oranje, L. Labrèze, J.-F. Stalder, J. Ring, and A. Taïeb, "Clinical validation and guidelines for the SCORAD index: consensus report of the European task force on atopic dermatitis," Dermatology, vol. 195, no. 1, pp. 10-19, 1997.

[12] M. Hald, Hand Eczema-Severity and Medical Attendance in relation to Prognosis, Vol. 61, Museum Tusculanum, Copenhagen, Denmark, 2009.

[13] E. Held, R. Skoet, J. D. Johansen, and T. Agner, "The hand eczema severity index (HECSI): a scoring system for clinical assessment of hand eczema. A study of inter- and intraobserver reliability," British Journal of Dermatology, vol. 152, no. 2, pp. 302-307, 2005.

[14] P. J. Coenraads, H. Van Der Walle, K. Thestrup-Pedersen et al., "Construction and validation of a photographic guide for assessing severity of chronic hand dermatitis," British Journal of Dermatology, vol. 152, no. 2, pp. 296-301, 2005.

[15] C. Skudlik, M. Dulon, U. Pohrt, K. C. Appl, S. M. John, and A. Nienhaus, "Osnabrueck hand eczema severity index-a study of the interobserver reliability of a scoring system assessing skin diseases of the hands," Contact Dermatitis, vol. 55, no. 1, pp. 42-47, 2006.
[16] M. Hald, N. D. Berg, J. Elberling, and J. D. Johansen, "Medical consultations in relation to severity of hand eczema in the general population," British Journal of Dermatology, vol. 158, no. 4, pp. 773-777, 2008

[17] V. Niemeier, M. Nippesen, J. Kupfer, W.-B. Schill, and U. Gieler, "Psychological factors associated with hand dermatoses: which subgroup needs additional psychological care?," British Journal of Dermatology, vol. 146, no. 6, pp. 1031-1037, 2002.

[18] J. M. Jordan and F. A. Whitlock, "Emotions and the skin: the conditioning of scratch responses in cases of atopic dermatitis," British Journal of Dermatology, vol. 86, no. 6, pp. 574-585, 1972.

[19] D. Böhm, S. Stock Gissendanner, F. Finkeldey et al., "Severe occupational hand eczema, job stress and cumulative sickness absence," Occupational Medicine, vol. 64, no. 7, pp. 509-515, 2014.

[20] A. Shirom, "Job-related burnout: a review," in Handbook of Occupational Health Psychology, J. C. Quick and L. E. Tetrick, Eds., pp. 245-265, American Psychological Association, Washington, DC, USA, 2003.

[21] S. M. Langan and H. C. Williams, "What causes worsening of eczema? A systematic review," British Journal of Dermatology, vol. 155, no. 3, pp. 504-514, 2006.

[22] G. Schmid-Ott, B. Jaeger, S. Meyera, E. Stephana, A. Kapp, and T. Werfel, "Different expression of cytokine and membrane molecules by circulating lymphocytes on acute mental stress in patients with atopic dermatitis in comparison with healthy controls," Journal of Allergy and Clinical Immunology, vol. 108, no. 3, pp. 455-462, 2001.

[23] I. Anveden Berglind, M. Alderling, and B. Meding, "Life-style factors and hand eczema," British Journal of Dermatology, vol. 165, no. 3, pp. 568-575, 2011.

[24] A. Garg, M. M. Chren, L. P. Sands et al., "Psychological stress perturbs epidermal permeability barrier homeostasis: implications for the pathogenesis of stress-associated skin disorders," Archives of Dermatology, vol. 137, no. 1, pp. 53-59, 2001.

[25] C. C. Zouboulis and M. Bohm, "Neuroendocrine regulation of sebocytes-a pathogenetic link between stress and acne," Experimental Dermatology, vol. 13, no. 4, pp. 31-35, 2004.

[26] I. Katayama, S.-J. Bae, Y.-i. Hamasaki et al., "Stress response, tachykinin, and cutaneous inflammation," Journal of Investigative Dermatology Symposium Proceedings, vol. 6, no. 1, pp. 81-86, 2001.

[27] F. S. Dhabhar and B. S. McEwen, "Enhancing versus suppressive effects of stress hormones on skin immune function," Proceedings of the National Academy of Sciences, vol. 96, no. 3, pp. 1059-1064, 1999.

[28] M. S. Al'Abadie, G. G. Kent, and D. J. Gawkrodger, "The relationship between stress and the onset and exacerbation of psoriasis and other skin conditions," British Journal of Dermatology, vol. 130, no. 2, pp. 199-203, 1994.

[29] L. Misery and A.-M. Roguedas, "Atopie et stress," Annales de Dermatologie et de Vénéréologie, vol. 131, no. 11, pp. 1008-1011, 2004.

[30] M. Vocanson, A. Rozieres, F. Frederic Berard, and J.-F. Nicolas, "Peau et immunologie-les eczémas. Nouveautés physiopathologiques sur l'eczéma de contact," Archives des Maladies Professionnelles et de l'Environnement, vol. 74, pp. 415-434, 2013.

[31] M. Altemus, B. Rao, F. Dhabhar, W. Ding, and D. Granstein R, "Stress-induced changes in skin barrier function in healthy women," Journal of Investigative Dermatology, vol. 117, no. 2, pp. 309-317, 2011.

[32] T.-K. Lin, M.-Q. Man, J.-L. Santiago et al., "Paradoxical benefits of psychological stress in inflammatory dermatoses models are glucocorticoid mediated," Journal of Investigative Dermatology, vol. 134, no. 12, pp. 2890-2897, 2014. 


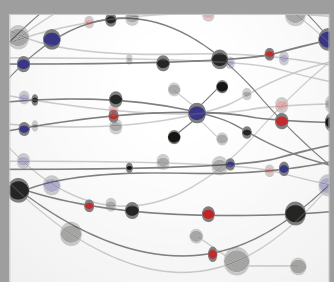

The Scientific World Journal
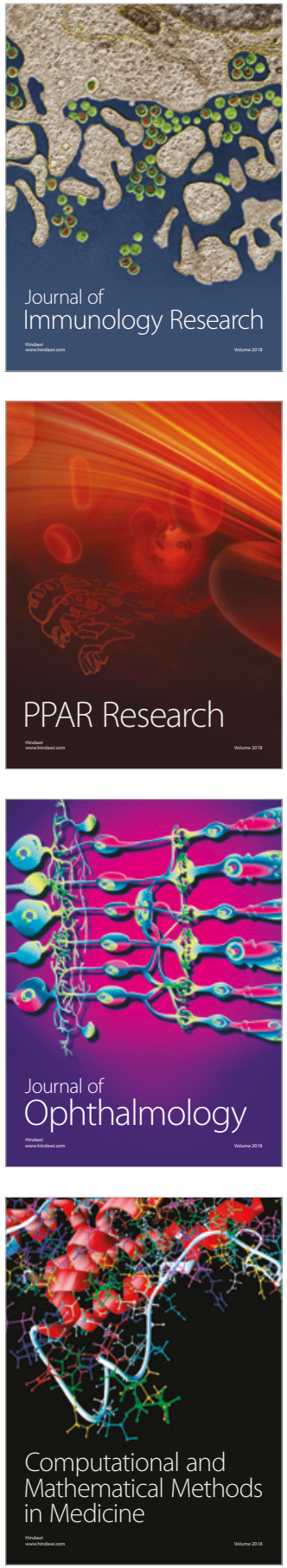

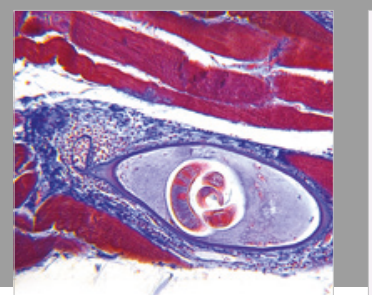

Gastroenterology Research and Practice

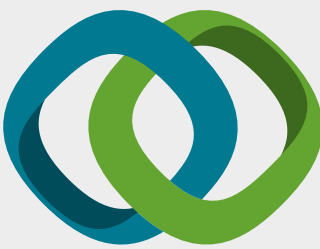

\section{Hindawi}

Submit your manuscripts at

www.hindawi.com
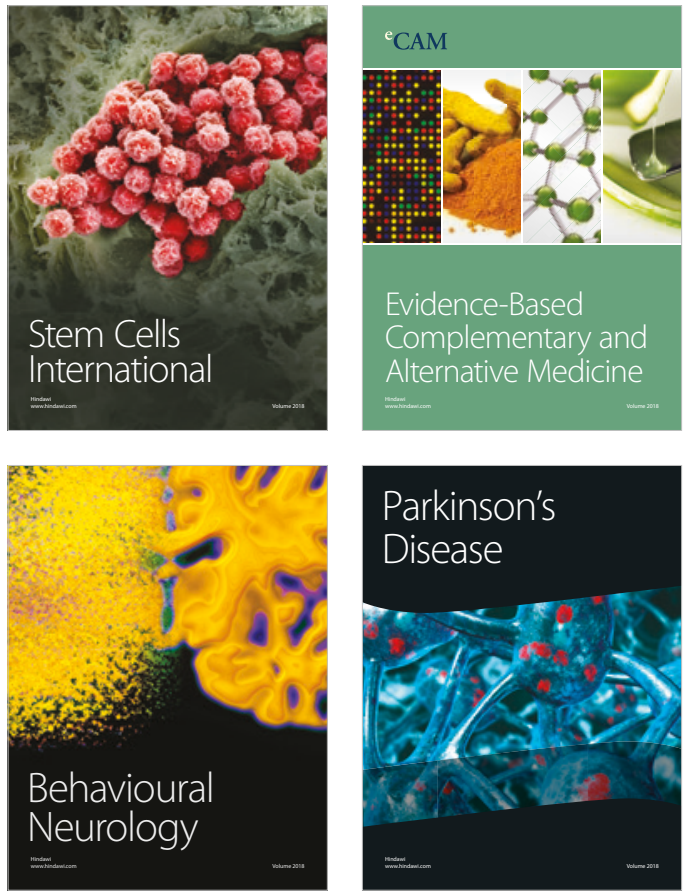

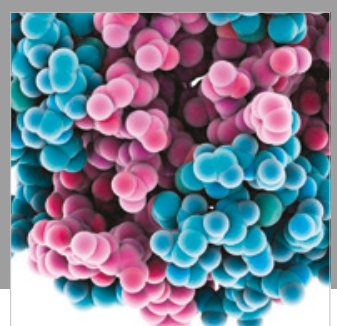

ournal of

Diabetes Research

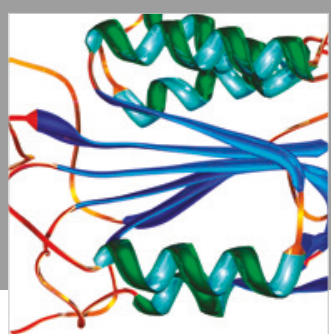

Disease Markers
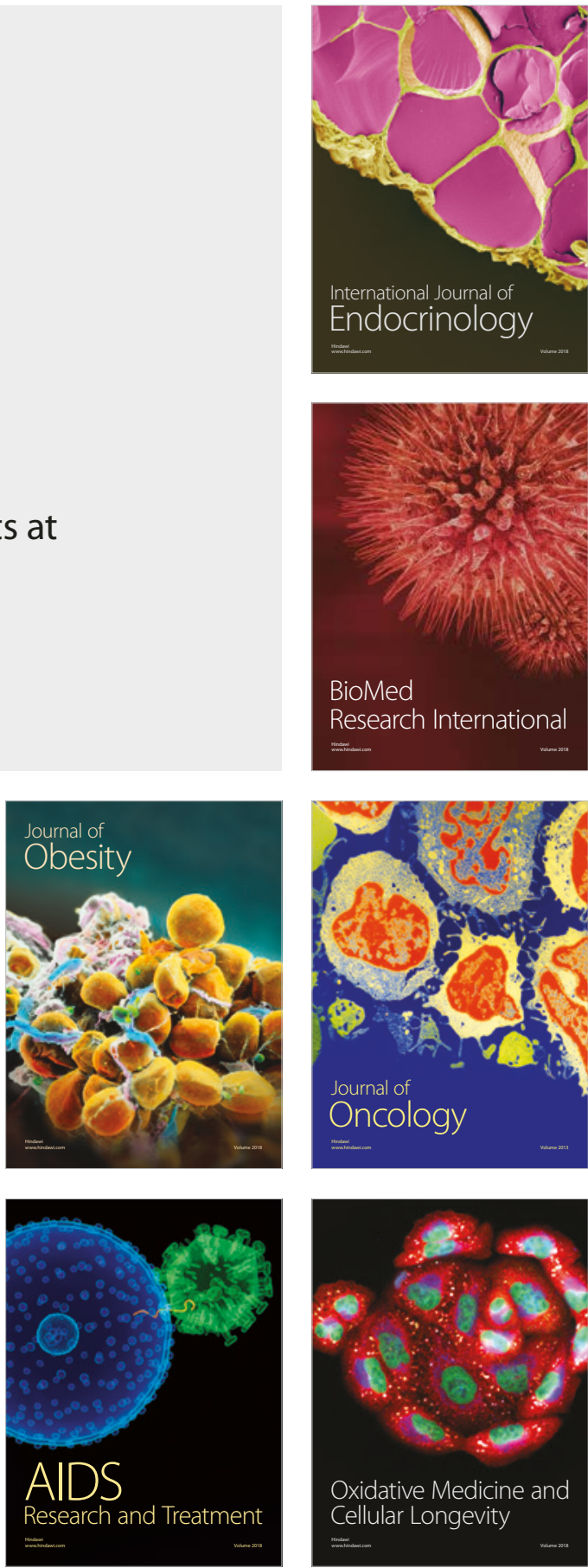